\title{
Introduction: Redefining the Role of Libraries in the Political Process and in Conflict Situations
}

\author{
Christine Stilwell, Raphä̈lle Bats, ANd \\ Peter Johan Lor
}

For better or worse, libraries are part of the fabric of society. They cannot survive and thrive as alien bodies nor, to use the language of systems theory, as closed systems with impermeable boundaries. It should therefore not surprise us that libraries are directly and indirectly affected, if not buffeted, by societal trends and perturbations. It remains shocking nevertheless when libraries are damaged or destroyed, especially when it appears that they have been deliberately targeted. A number of recent cases of this nature prompted the Library Theory and Research (LTR) section of the International Federation of Library Associations and Institutions (IFLA) to propose the topic "Libraries in the Political Process: Benefits and Risks of Political Visibility" as the theme for its open session held at the IFLA World Library and Information Congress in Lyon, France, in August 2014. This topic was aligned with the global theme of the IFLA 2014 Congress, "Libraries, Citizens, Societies: Confluence for Knowledge."

IFLA has over sixty sections and interest groups dealing with current topics of all kinds. Within this constellation, LTR has a particular responsibility to select themes that require rethinking and theoretical reflection at a fundamental level, or that present methodological challenges. Accordingly, the LTR Standing Committee called for papers responding to the challenge of rethinking library roles in relation to the publics we serve in times of crises of all kinds, including political, financial, and managerial crises and crises of professional identity. Participants were asked to look in a scholarly way at these phenomena, not limiting the session to descriptions of the incidents or the defense of libraries, but considering also the profession's responses and what they say about the way the profession is conceptualizing its role in society.

This issue of Library Trends has its origins in the open session that followed. After a rigorous peer-review process, at least half of the submissions were judged to be of an acceptable level, but only five of them could be ac- 
commodated in the program. Unfortunately, two of the selected presenters were unable to participate in the session, Joseph Belletante (France) and Hasan Keseroğlu (Turkey). In the end, three papers were presented at the session, by Tim Huzar (United Kingdom), Amanda Click and Josiah Mark Drewry (United States), Mahmoud Khalifa (Egypt), and Genevieve Hart and Mary Nassimbeni (South Africa). Peter Johan Lor was asked to present an introduction to the session. In light of the high quality of the proposals, after the session the LTR Standing Committee decided to seek a publication outlet for the papers that had been presented, as well as for papers based on the most highly ranked proposals that could not be accommodated at the conference. Many were not able to comply, and in order to compile a balanced and complementary set of papers,, a number of additional contributions were invited, yielding those by Raphaëlle Bats, Denis Merklen, and Ian Johnson. In addition, Christine Stilwell was invited to serve as a coeditor of the special issue, along with Lor and Bats.

The authors represented in this special issue come from a variety of backgrounds-geographic, professional, and scholarly. Three authors and an editor are from France; three authors and two editors are from South Africa; one author is from the United Kingdom, though with extensive international experience and knowledge of the Arab world; and another is from Canada. The last is from Turkey. This issue represents many voices and topics within the overarching theme of "libraries in the political process." Three broad metathemes were envisaged-libraries in the political process, defining the role of libraries, and libraries in situations of political and social conflicts-but the papers diverge, converge, and intersect at many points, as in a braided river, ${ }^{1}$ so that it is difficult to group them according to this scheme. Other themes, such as library neutrality and libraries and democracy, emerged.

Librarians often complain that libraries are overlooked or taken for granted. But when libraries appear in the headlines, it may be a mixed blessing. The papers included in this issue cover the spectrum of bad and better news, touching on the conundrum posed by the deliberate targeting of libraries in the pieces by Lor, Belletante, and Merklen at the one end, and at the other describing a postapartheid initiative that envisages a transformed and integrated library system that has meaning to all sectors of South African society in the paper by Hart and Nassimbeni.

By political process, we mean "the process of the formulation and administration of public policy usually by interaction between social groups and political institutions or between political leadership and public opinion" (Political process, n.d.). The papers touch on these processes either explicitly or implicitly. The first is by Lor, and the stimulus for his piece, "Risks and Benefits of Visibility: Librarians Navigating Social and Political Turbulence," lay in the deliberate burning of libraries, and in particular the occurrence of such events in peacetime in democracies. Lor is an ex- 
traordinary professor in the Department of Information Science of the University of Pretoria in South Africa. He asks what such destruction says about community perceptions of libraries and interrogates the response of the library profession. He also asks important questions about the visibility of libraries and lack thereof in the political process, and about how visibility is raised. Lor does not define visibility per se, but the Oxford English Dictionary states that it is "the condition, state, or fact of being visible," having a "visible character or quality" or the "capacity to be seen (in general or under special conditions)." The term can also be used figuratively to mean "the degree to which something impinges upon public awareness" or its "prominence" (Visibility, 1989, p. 687). In terms of our theme, the greater the prestige of a library, the greater its visibility. In Lor's paper the term is used to include political visibility, being visible, or having prominence in the political sphere. Implicit in this notion of visibility is the attention given to libraries by stakeholders such as community members and in the media.

The visibility and invisibility of libraries confer risks as well as benefits, and Lor puts forward a theoretical model of the relationship between visibility and risk. He illustrates this relationship by referring to library development in South Africa, concluding that the risks of invisibility outweigh those of visibility, but that the political awareness and commitment of the library profession are critical. Lor's model is derived from his introductory paper to the LTR's session and is intended to set the scene for this special issue of Library Trends. The variety of papers submitted pushed the boundaries of his scheme, but nonetheless it serves the purpose of stimulating further questions and is used to present the other papers herein. Some of the themes that emerged are described below.

\section{Library NeUtrality}

A strong theme in this issue is that of library neutrality. Lor refers to the idea that the library, in its collections and services, should be neutral and have "no religion, no politics, no morals" (p. 120). He points out that this quotation from the title of a talk by D. J. Foskett in 1962 is often quoted out of context (Brewerton, 2003, p. 48) and explains Foskett's point "that the librarian should not impose his/her own political, religious, or moral outlook on library users, but not that the librarian should lack political, religious, or moral values. Indeed, the role of the librarian calls for dedication, itself a professional value" (p. 124). Lor goes on to suggest that in conditions of social injustice, traditional library neutrality is effectively an endorsement of the status quo. A more critical stance and greater engagement with issues of social justice on the part of librarians can augment the visibility and relevance of libraries, albeit not without risk.

The issue of neutrality and how it is challenged in conflict situations runs through two of the papers from France (Bats's and Merklen's). In 
"Libraries after Charlie: From Neutrality to Action," Bats analyzes the reaction of French librarians to the January 2015 attacks against the satirical newspaper Charlie Hebdo and the kosher supermarket Hyper Cacher. She is conservateur de bibliothèque at the Ecole Nationale Superieure des Sciences de L'information (ENSSIB) Lyon, the national school of library and information science in France, and interim coordinator of its master's program, Politiques des Bibliothèques et de la Documentation. For the survey Bats describes, she draws on social media-Twitter in particular-to collect data and analyze the actions carried out by libraries after "Charlie," as the French call the tragedy. She uses both events as an opportunity to question the political role that libraries have assigned to themselves, and examines how libraries and librarians have reconciled their own requirement of neutrality with their desire to take part in these highly political events. Her analysis of the actions taken and activities staged by libraries after Charlie is of particular interest because it discusses librarians stepping outside the box of neutrality to align themselves with a nationwide movement, and also because the event that triggered these library responses does not fit neatly into the usual repertoire of librarians' public actions, such as fighting attempts to impose censorship or ideological orthodoxy. These actions challenge our understanding of the freedom of expression and democracy. Against the background of the unique French concepts of democracy, the state, and founding values of the République Française, she analyzes the threefold requirements of neutrality that arise from the mission of the library, republican values, and the duties of the public servant, thus reflecting on the limitations of the political independence of librarians and their neutrality, as opposed to that of the library. Bats argues for a need to rekindle the activist vocation of the library, which brings us to the theme of the role of the library.

\section{THE Role OF THE LibRARY}

The role of the library and its nature are explored in some depth in Merklen's contribution to this special issue, "Is the Library a Political Institution? French Libraries Today and the Social Conflict between Démocratie and République." Merklen is a professor of sociology at the Université Sorbonne Nouvelle in Paris. His latest book, Pourquoi brûle-t-on des bibliothèques? (Why are people setting fire to libraries?), published in 2013, explores different forms of violent conflict between public libraries and the inhabitants of France's low-income suburbs.

Merklen also commences his paper with reference to the destruction of public libraries in the banlieues - the outlying districts of French cities. These districts sometimes face violent conflicts within the context of social, cultural, and political changes. Such events have increased during the previous fifteen years, and librarians, caught in the middle, are faced with diverse conceptions of the political role of libraries. Merklen regards 
them as wavering between the concepts of démocratie and république and the social aspects of libraries that feature in conflicts in which the classes populaires (working classes) are protagonists.

Merklen discusses how local libraries went from being bibliothèque populaires (working-class libraries) to an agency for promoting reading among the general public, and from being controlled by civic society to the control of the municipality. He highlights how these libraries now belong to the cities or local governments. This evolution means that "libraries are now strong institutions, with established budgets, rich collections, and qualified staff members" (p. 148). Librarians, as a result of the same phenomenon, are no longer activists who belonged to several social, political, or religious organizations as radicals, socialists, communists, or Catholics; they have become state employees, "professionals of la lecture publique (public reading)" (p. 148). Merklen further explains that "Librarians became a specialized category with its own training from particular schools for specific qualifications. They have their own professional organizations, such as the Association de Bibliothécaires de France (Association of French librarians), and their own ethical codes, which include their requirement of neutrality" (pp. 148-149).

This view provides an interesting perspective on the professional challenges highlighted by Bats. The theme of the location of responsibility for public libraries and the processes that lead to their establishment, their role, and the implications of their location reoccurs in various contributions to this special issue. This theme resonates with the views of Bertrand (2009, p. 477), who, in a comparison of the "genealogy" of North American and French public libraries, argues that unlike those in the United States where local initiatives play a major role, French public libraries have not been created by and for the people, but instead handed down from above, thereby echoing some of Merklen's concerns. Merklen provides a useful background on some key French political and sociological concepts, therefore it would be helpful to read his contribution before that of Belletante.

Belletante, in his paper "Putting Crises behind Us: A New Opportunity for Libraries," also explores the library's role and how it is changing. Belletante is the director and curator of the Museum of Printing and Graphic Communication in Lyon, France, where he researches new media and visual studies, cultural practices, and discourse studies. He also considers the issue of the deliberate burning of libraries, but suggests that such crises provide a political opportunity for all libraries, and in particular French libraries-or their current multimedia manifestation, the médiathèques- to achieve a conception of the future of libraries that goes beyond Oldenburg's (1989) "great, good places." Belletante urges the library to use its ability to deploy the available social and other media to provide a type of support to local individuals that is both more global and assertive. Specifi- 
cally, he sees new or expanded roles for libraries in providing programs of social support to citizens who are demoralized by unemployment, as well as support for bottom-up cultural initiatives and local government. The latter is perhaps Belletante's most interesting departure, since he argues for sharing with local government the expertise developed by libraries and museums in researching community needs, and in the planning of programs to address these needs. Two additional, typically French library phenomena are worth noting: the close relationship of libraries and museums, and the quite un-Anglo-Saxon-like French response to declining local government support for libraries. It is a telling illustration of Bertrand's (2009) thesis that Belletante does not mention the option that would have been the most obvious to U.S. librarians: mobilizing the library's support base within the local community.

\section{Between Benign Neglect and Cynical Exploitation}

In an ideal world-perhaps a fool's paradise?-governments and other oversight bodies would provide generous funding for libraries while applying an arm's-length policy, leaving librarians to apply the resources in accordance with their professional insights and principles. But in the real world, "he who pays the piper calls the tune." ${ }^{2}$ The four remaining articles all deal in one way or another with the relationship between governments and libraries. On the part of governments, this ranges from neglect to exploitation: neglect is a risk in situations where libraries have low visibility, whereas high visibility may trigger exploitation. Occasionally there are elements of both, as in the cases of Canada and Turkey.

From her base in Toronto, Mary Kandiuk, in "The Rhetoric of Digitization and the Politicization of Canadian Heritage," suggests that Canadian heritage institutions were being used as political instruments to advance the previous government's ideological agenda. She is the visual arts, design, and theatre librarian at York University Libraries in Toronto. Kandiuk argues that budget cuts and increased control by the federal government have led the national Library and Archives of Canada (LAC) to abdicate its stewardship role regarding the nation's collections and records and to focus instead on government priorities. She examines the priorities of LAC with respect to digitization and (unfunded) decentralization through devolution of its responsibilities to other institutions in Canada's provinces. Kandiuk argues that these two priorities have undermined LAC's ability to fulfill its responsibility for the preservation of, and access to, materials. Of particular concern are the further barriers to access created by LAC for underserved populations, including Canada's Indigenous peoples.

Kandiuk also considers a related theme: the dangers of managerialism, of an excessive focus on the technicalities of digitization, marketing, and the promotional events that may cause librarians to lose sight of their val- 
ues (also mentioned by Lor). In the Canadian case, heavy-handed managerial interventions on the part of the federal government led to restrictions on the academic freedom of LAC staff and internal dissent, as well as savage cutbacks in services that were important to various user communities. These interventions were motivated by a neoliberal "small government" philosophy with a nationalistic flavor. The government tried to kill two birds with one stone: to balance the federal budget in line with electoral promises, and at the same time to divert funds to patriotic nation-building projects. Large-scale digitization projects served as a smokescreen for all this.

In the case of Turkey, Hasan Keseroğlu's "Politics and Public Libraries in the Republic of Turkey" explores the phenomenon of the absence of public libraries from the politics and agenda of the country. Keseroğlu is a professor, founder, and since 2010 the head of Bilgi ve Belge Yönetimi Bölümü (Department of Information and Records Management) in the Faculty of Science and Letters of Kastamonu University in Turkey. He has done extensive research on public library policy in Turkey and on the libraries of the Ottoman Turks. In his contribution Keseroğlu considers post-Ottoman library development, arguing that the library as a social institution is an indispensable component of the dynamics of any democratic country. The successes and failures of such institutions are directly proportional to the understanding of democracy, and he concludes that unstable politics and the involvement of politicians in the operations of libraries hinder public libraries in performing their role. In fact, Keseroğlu takes the common notion of libraries as instruments or facilitators of democracy (what libraries should do for democracy) and turns it on its head, viewing public libraries as a measure of democracy (what true democracy should do for libraries). In his view, democracy in Turkey is still dysfunctional because it has not been "indigenized" nor internalized-it has not yet become an integral part of the political culture. This state of affairs is reflected in the development of public libraries in Turkey, which has been impeded by apathy and neglect, as well as by opportunistic interference and exploitation on the part of the national government. Politicians, Keseroğlu argues, should be aware and supportive of libraries without interfering in professional functions like collections development-a somewhat idealized view of the public library situation in Western democracies. From this point of view, Turkish democracy is bedeviled by confusion between the role of the state and that of the governing party. This problem is by no means limited to Turkey, but affects the library situation in many emerging and developing countries throughout the world-something that would repay further study. 


\section{Politics, Visibility, and Library Development}

The complex relationship between libraries and democracy also features in Genevieve Hart and Mary Nassimbeni's "Libraries and a 'Better Life for All': The Politics, Processes, and Promises of the South African LIS Transformation Charter." They examine "the confusing fortunes of the country's libraries" (p. 199) in South Africa since the advent of democracy in 1994. Like Keseroglu, they find inspiration in Western democracies, but in their case emphasize the role of libraries in support of democracy, citing Andrew Carnegie and more recent North American authorities like the American Library Association (ALA) that view public libraries as "cradles," "beacons," "hothouses," and "cornerstones" of democracy. Hart and Nassimbeni identify the "rhetoric of public librarianship ... for the role of libraries" (p. 199) in the twenty-two-year-old democracy in which the library and information services (LIS) profession portrays libraries as agents of development and social transformation. They also note that since 2009, more than twenty South African libraries have been destroyed in social protests. Hart is extraordinary associate professor in the Department of Library and Information Science of the University of the Western Cape, and Nassimbeni is an emeritus professor in the Library and Information Studies Centre of the University of Cape Town.

These authors analyze the political and professional forces that influenced the writing of the LIS Transformation Charter, which was presented to the national government in 2014 after six years of stop-start deliberations. Both Hart and Nassimbeni are coauthors of the report that emerged from this lengthy project, and they were immersed in the processes that led to its production. Their account of these processes is of interest, inter alia, because it illustrates the importance of aligning library-development objectives with those of national development, and of seizing an opportunity offered by a major national upheaval and rethinking of roles and priorities. Traumatic disruption and a national sense of crisis, together with the availability of foreign models, constitute conditions favorable to largescale, international policy transfer and restructuring within the affected countries (Djelic, 1998, pp. 66-69).

To gain government support, the charter team emphasized the "value proposition" (p. 211) of libraries, adopting rhetoric presumed to "sugar the pill" for the holders of the purse strings-the pill being an investment in reorienting and developing the national library system. It remains to be seen to what extent a charter such as the South African LIS Transformation Charter can assist in addressing some of the problems of access and equity identified in this special issue. Amid the struggle to establish, upgrade, and resource public libraries and develop the charter to underpin the efforts of offering equal service to all in South Africa came the destruction of some public and school libraries and a university library by acts of violence. The charter appears to place a good deal of emphasis on inputs 
and initiatives by the central and provincial governments. In this regard Bertrand's (2009) views, cited earlier, on French public libraries remain pertinent; namely, her observation that French public libraries have not been created by and for the people, but instead handed down from above. Merklen highlights that French libraries went from being at the service of civic society to being at the service of the municipality, and that librarians are no longer activists but have become state employees. These observations have implications for assigning responsibility for public libraries in other countries, and for the processes that lead to their establishment. Writing as devil's advocates, we wonder: could central and provincial government involvement prove to be a retrograde step, in that healthy public libraries need to be rooted in the communities they serve? This point is also eloquently made by Belletante in this issue. ${ }^{3}$

It is interesting that Hart and Nassimbeni's concerns mirror some of those of Kandiuk because two fundamental arguments of the LIS Transformation Charter are access to information and thus to libraries as a fundamental justiciable human right. Hart and Nassimbeni are also particularly concerned, as the title of their article suggests, about access to libraries and information for all of South Africa's citizens, especially those disenfranchised and ill-served during the apartheid years. These authors, and the larger team responsible for producing the charter, adopted an "ecosystems" approach to the problem. Drawing on the work of Nardi and O'Day (1999), Hart and Nassimbeni describe "an ecosystem as one in which the subsystems are interlinked and interdependent and where there is continuous co-evolution, change is systemic, and where complementarity encourages niches for different roles and functions" (p. 209), and perceive the relevance of this approach lying in its being characterized by the interactions of "actors and organizations linked by flows of resources and information" (Mars, Bronstein, \& Lusch, 2012, p. 277). Hart and Nassimbeni argue that the ecosystems concept captures the diversity and complexity of South African library and information services and the necessary interaction between the system (or "organism" in ecological terms) and its environment. In South Africa all three tiers of government (central, provincial, and local) are involved in LIS policy, funding, and delivery, and these authors conclude that the final LIS Transformation Charter maps a path for an integrated library system that has meaning for all sectors of South African society.

As previously noted, the development of the charter occurred against the background of the burning down of libraries in South Africa. This recalls the role of visibility in the destruction of libraries, and the link between relevance and visibility that Lor highlights in his paper. In the French case, libraries were targeted by disaffected youths of mostly foreign extraction (mainly from the Arabic-speaking Maghreb) as a form of protest against a literate culture that excluded them and an education system 
that emphasized literacy and literature, which they felt had alienated and failed them. In the South African case, the reasons why protesters set fire to libraries are not clearly articulated; some explanations by protesters cited in the press and in Von Holdt et al. (2011) may be more ex post facto rationalizations for spontaneous actions rather than political rationales. The lasting influence of the behavior patterns of the struggle for democracy in South Africa may also have played a role. All citizens can vote, but if elected representatives fail them, the communities (or leading subgroups) turn to tried-and-tested tactics that were used during the struggle against apartheid. In the South African case, perhaps, the libraries were both visible and invisible-visible in that they were located adjacent to, or as part of, civic centers that were identified with injustice and repression and were targeted during the struggle; and invisible in the sense that libraries do not have much impact or meaning or carry much symbolic value.

It is worth noting that Hart and Nassimbeni take a more nuanced approach to democracy than might be inferred from the rhetoric they cite in the introduction to their piece. While South Africa is a constitutional democracy, the constitution alone does not suffice to guarantee democratic governance. Libraries are seen as facilitating "participatory" and "deliberative" democracy (pp. 202-204). The limitations of a democratic constitution are vividly illustrated in Keseroğlu's article, a theme also highlighted by both Merklen and Belletante. In established Western democracies also, constitutional or representative democracy is in trouble. The political establishment is not trusted, and voters respond with apathy or by turning to extreme populist figures, both to the Left and Right, regarded by voters as untainted by the establishment, thus resulting in the erosion of the center. In this connection the suggestion by Hart and Nassimbeni, also mentioned by Belletante, that libraries should contribute to social cohesion is of interest, albeit problematic.

While Hart and Nassimbeni focus on a specific, structured policy-development initiative, Johnson's article, "Under-Resourced, Inadequately Staffed, and Little Used: Some Issues Facing Many School Libraries, Seen through the Lens of an Exploration of the Situation in Iraq," draws on a wider case study of the development of librarianship and information management in Iraq. In this paper the focus is on school libraries and those of the Arab world and Iraq in particular. Johnson is a professor in the Department of Information Management of Robert Gordon University in Aberdeen and has worked on development projects in the Middle East, Eastern Europe, and Latin America, and he is currently the editor of IFLA's book series Global Studies in Libraries and Information.

Both Iraq and Turkey are successor states of the Ottoman Empire, but although their histories diverged, both Johnson and Keseroğlu recount similar slow and tortuous developmental paths, punctuated and interrupted in the case of Iraq by wars and regime change. A theme common 
to both articles is that of a lack of recognition of the potential value of libraries: their lack of visibility and relevance to society. Johnson asks why in many countries, including wealthy, industrialized ones, "school libraries may not have been seen as an essential element of education, and supported and used accordingly" (p. 217). He considers the provision of school libraries within the context of a country's economic, political, and social circumstances, and reviews the encouragement for the development of literacy, education, and school libraries offered by the international agencies, both intergovernmental organizations and international NGOs. He notes, inter alia, the way in which some reports were "edited" (censored) to remove recommendations regarded as unwelcome by the sponsoring organization.

Johnson's contribution adds yet another level of politics to library development. In addition to describing organizational initiatives and structural factors, he identifies a need to transform perceptions of school libraries' contributions to a country's development, draws conclusions about issues in mobilizing support for development, and points to the lack of focused and coordinated efforts by relevant international agencies. He also highlights the shortcomings in the advice proffered to Iraq and other Arab states by international professional and intergovernmental organizations. Johnson provides informative, detailed insights into library development in Iraq and library-development issues more generally. An important conclusion is that librarians need to understand "that policy choices have to be made when resources are finite, and that the challenge is to get school libraries visible on the policy agenda" (p. 244), which brings us back to the theme of visibility that was broached by Lor.

All the contributions to this special issue deal in one way or another with libraries within the political process, and there are interesting similarities and differences. In Turkey's case, there is much emphasis on government measures such as political party platforms, legislation, and various developmental plans; the political process is dominated by government. In the Canadian case, there is much more emphasis on the role of civic society-on librarians, archivists, and the Canadian Association of University Teachers. In Johnson's paper, international professional organizations play an important role, although he does identify problems regarding what he identities as "their immediate relevance, practicality, and lack of demonstrated benefits, as well as the absence of consistency and unanimity in those recommendations" (p. 243).

What emerges from these contributions is a general theme of neglect because governments do not give libraries much attention or priority; for example, in Turkey's case libraries seem to be part of the political spoils system (by appointing party members to library positions regardless of competence). Johnson's discussion of school libraries in Iraq reflects a lack of priority and fluctuating interest on the part of government officials. 
Here, the role of individuals taking initiatives and providing leadership seems to be important. In the Canadian case the LAC suffered because of austerity measures and new priorities aligned with the government's neoliberal ideology. Digitization in relation to this ideology is an interesting theme. The South African contribution of Hart and Nassimbeni also features the political process at the federal level of government (as does Keseroğlu's), and here it is interesting to note how the library promoters had to adapt their ideas and adopt a theoretical model (the ecosystem approach) that appealed to important government and African National Congress figures.

\section{Concluding Comments}

We noted that in his article, Merklen uses a transition or shift from French, which is his usual working language, to English in order to highlight the place of libraries in the political sphere of contemporary French society. In doing this he raises issues of language, identity, and translation-issues that presented major challenges to the coeditors. We engaged in many rounds of querying points and meaning, back and forth with the authors and other intermediaries (a translator and a coeditor fluent in French) about the precision of their understanding of the complex notions and terminology expressed in the French articles. Two of the three articles about France (Bats's and Belletante's) were first written in French and then translated.

What is interesting about these French articles is that they appear to be more philosophical and sociological, particularly in relation to new media, thus delivering a more overtly scholarly approach and a rethinking of the roles of libraries and librarians in society at both the fundamental and the philosophical levels. In commenting on Merklen's contribution, the editor of Library Trends, Alistair Black, placed some of these issues from a French societal context into a wider perspective and relationship with events in the United States and United Kingdom. They are also highly pertinent to South Africa, although none of the papers in this special issue focus specifically on the influence of community librarianship on this or other societies. As Black commented,

This is a very interesting analysis of the overriding tension in service delivery-between giving readers what they want or what professionals think they need-experienced by librarians over the past thirty to forty years. It is a tension that has been prevalent outside France too. In the US, the ' 60 s and '70s saw the rise of the "social responsibility in librarianship" movement, which sought to prioritize services to the "information poor." This was replicated in Britain, in the ' 80 s, in the form of the "community librarianship" movement, which rejected the traditional, apolitical stance of librarians and placed at the top of the service agenda services to the disadvantaged with the aim of assisting the redistribution of wealth. It's fascinating to see how these tensions 
continue to be played out. (A. Black, personal communication, May 19, 2016)

Perhaps the most important theme to emerge from these contributions, and one that leads from the comments by Merklen in his paper, is the critical need for political awareness and commitment in librarians. In other articles, Lor identifies this need and Belletante urges the library to use its ability to deploy the available social and other media to provide more global and assertive support to local individuals. Bats also argues for a need to rekindle the activist vocation of the library. Merklen casts the library as a political actor that aims for social transformation, asking, "Is the library a democratic, open, and diverse institution in which everyone, all citizens, can find their place?" (p. 152). These are challenging questions for librarians and libraries, and the coeditors of this special issue on "Libraries in the Political Process" hope that in presenting them here, with the help of the article authors, we will make a contribution toward moving forward the discourse in the profession.

\title{
ACKNOWLEDGMENTS
}

The coeditors of this special issue would like to thank the article authors for their commitment, insightful contributions, and apparent patience in responding to their many queries. The coeditors' grateful thanks also go to Cindy Ashwill and Alistair Black for their invaluable assistance and support. Finally, they would also like to thank the translators (including Peter Lor), copyeditors (including Barbara Gentil), and the entire production team.

\section{Notes}

1. A "braided river" is an appropriate simile; such rivers flow strongly and unpredictably, carrying a heavy load of sediment.

2. Margaret Atkins (2003) has commented (within the context of higher education and public services in the UK) on the use of this proverb and its history in a manner that resonates with the substance of our introduction:

\begin{abstract}
After a further decade and a half the consequences of acting in the spirit of a certain interpretation of that proverb are becoming all too apparent in the wider field of education, and indeed throughout the public services. "Micromanagement" is everywhere: the paymaster is calling all the tunes, providing detailed instructions to the pipers as to how to play each note, and then checking that he has obeyed the instructions (or at least that he can make a show of providing evidence that he has obeyed instructions). It would be surprising under these circumstances if the pipers were to play musically, let alone to enjoy their playing. (n.p.)
\end{abstract}

She asks, "How ought I to have challenged the assumption that the paymaster is the right person to decide the way in which the piper should account for how and what he plays?"; she further points out that the phrase "pay the piper" predates the longer version by some centuries and "was used simply to mean 'bear the cost,' with no reference at all to controlling the piper's playing."

3. In South Africa, both federal and provincial government intervention has been regarded as necessary because of the low city and municipal tax bases and the lack of administrative capacity in some municipalities (Stilwell, 2011, p. 59; 2016, p. 132). 


\title{
REFERENCES
}

Atkins, M. (2003). Should he who pays the piper call the tune? CUCD Bulletin, 32. Retrieved from https://www.royalholloway.ac.uk/classics/cucd/atkins.html

Bertrand, A.-M. (2009). Inventing a model library "à la française." Libraries and the Cultural Record, 44(4), 471-479.

Brewerton, A. (2003). The creed of a librarian: A review article. Journal of Librarianship and Information Science, 35(1), 47-55.

Djelic, M.-L. (1998). Exporting the American model: The postwar transformation of European business. Oxford: Oxford University Press.

Foskett, D. J. (1962). The creed of a librarian: No politics, no religion, no morals. London: Library Association.

Mars, M. M., Bronstein, J. L., \& Lusch, R. F. (2012). The value of a metaphor: Organizations and ecosystems. Organizational Dynamics, 41(4), 271-280.

Merklen, D. (2013). Pourquoi brûle-t-on des bibliothèques? [Why did they burn libraries?]. Villeurbanne, France: Presses de l'ENSSIB.

Nardi, B., \& O’Day, V. (1999). Information ecologies: Using technology with heart. Retrieved from http://firstmonday.org/htbin/cgiwrap/bin/ojs/index.php/fm/article/view/672/562

Oldenburg, R. (1989). The great good place: Cafés, coffee shops, bookstores, bars, hair salons, and other hangouts at the heart of a community. Boston: Da Capo Press.

Political process. (n.d.). In Merriam-Webster dictionary. Retrieved from http://www.merriam -webster.com/dictionary/political process

Stilwell, C. (2011). Poverty, social exclusion, and the potential of South African public libraries and community centres. Libri, 61(1), 50-66.

Stilwell, C. (2016). Public libraries and social inclusion: An update from South Africa. In U. Gorham, N. Greene Taylor, \& P. T. Jaeger (Eds.), Perspectives on libraries as institutions of human rights and social justice (pp. 119-146). Bingley, UK: Emerald.

Visibility. (1989). In J. A. Simpson \& E. S. C. Weiner (Eds.), Oxford English dictionary (2nd ed.). Oxford: Oxford University Press.

Von Holdt, K., Langa, M., Molapo, S., Mogapi, N., Ngubeni, K., Dlamini, J., \& Kirsten, A. (2011, July). The smoke that calls: Insurgent citizenship, collective violence and the struggle for a place in the new South Africa. Eight case studies of community protest and xenophobic violence. Johannesburg: Centre for the Study of Violence and Reconciliation/Society, Work and Development Institute, University of the Witwatersrand. Retrieved from http://www.csvr .org.za/docs/thesmokethatcalls.pdf

\begin{abstract}
Christine Stilwell holds a PhD degree and is a professor emeritus of the University of KwaZulu-Natal (UKZN) in South Africa. She served as the head of the Information Studies Programme (2003-2007), as acting director of the Centre for African Literary Studies (2011-2013), and as an Advisory Board member of the Alan Paton Centre and Struggle Archives at UKZN. She has experience as a practitioner in the public library sector, and her early research focused on community libraries and the role of public libraries in postapartheid South Africa. She has published two coedited books, a directory of South African resource centres, many chapters in books, and numerous journal articles. She serves on the editorial advisory boards of several international and South African journals, and is currently a member of the advisory board of the Carnegie Continuing Professional Development Programme at the University of Pretoria. Her research interests include public libraries and their role in addressing poverty and social exclusion, and information behavior. In 2014 she was awarded a fellowship by UKZN.
\end{abstract}

Raphaëlle Bats is conservateur de bibliothèque at the Ecole Nationale Superieure des Sciences de L'information (ENSSIB) Lyon, France's national school of library and information science, where she serves as the international relations officer and interim coordinator responsible for the master's program, Politiques des Bibliothèques et de la Documentation. She is currently working on a doctoral thesis in philosophy and sociology titled "From Participation to Collective Action: French 
Libraries in Search of a Democratic Vocation." She is the editor of a book dedicated to participatory projects in French libraries, Construire des Pratiques Participatives en Bibliothèque, published in 2015, and has been involved in the Library Theory and Research section of IFLA since 2011.

Peter Johan Lor holds a D.Phil. degree (1991), as well as an honorary doctorate (2008), from the University of Pretoria (UP). He held positions in special and academic libraries and as a professor of library science at the University of South Africa before becoming the director of the State Library in 1992. He was South Africa's first National Librarian (2000-2003), and from 2005 to 2008 he served as secretary general of the International Federation of Library Associations and Institutions. From 2009 to 2011 he was a visiting professor in the School of Information Studies at the University of Wisconsin-Milwaukee, where he continues to teach an online course in international and comparative librarianship. Now an extraordinary professor in the Department of Information Science at UP, he is privileged to work online from his home in Sedgefield, on the South African Garden Route. His current research focuses on international and comparative librarianship, and on the ethical and political economic aspects of international information relations. 